Reprod. Nutr. Dévelop., 1987, 27 (2 A), 413-422.

\title{
Effects of age and live weight on fat $5 \alpha$-androstenone levels in young boars fed two planes of nutrition
}

\author{
M. BONNEAU
}

with the technical assistance of G. CONSEIL, Francoise GIOVANNI, Anne-Marie MOUNIER, Y. PEIGNIER

Station de Recherches Porcines, I.N.R.A., Saint-Gilles, 35590 L'Hermitage, France.

\begin{abstract}
Summary. The aim of the present experiment was to determine whether age, live weight, or a combination of both, was the most important factor influencing fat $5 \alpha$-androstenone levels in male pigs. Three groups of 50 boars each were fed either on a liberal plane of nutrition (CTRL group) or were restricted (SW and SA groups). Fat $5 \alpha$-androstenone was measured three times in each pig (on biopsies at two different times and at slaughter) at either the same live weight (SW) or at the same age (SA) as CTRL boars. In addition, the genital tract was dissected at slaughter.

SW boars (aged 169 days) exhibited higher fat $5 \alpha$-androstenone levels than CTRL boars (aged 139 days) when the first biopsy was taken at $80 \mathrm{~kg}$ of live weight $(1.2 \mathrm{vs}$ $0.8 \mu \mathrm{g} / \mathrm{g} ; \mathrm{P}<0.05)$. By the time of the second biopsy $(100 \mathrm{~kg}$ of live weight $)$ and at slaughter $(125 \mathrm{~kg})$ there was no significant difference between the SW and CTRL groups, although the SW were $43-55$ days older than the CTRL. At all three measurement times, fat $5 \alpha$-androstenone was lower in SA than in CTRL boars which were 21-36 kg heavier $10.5 \mathrm{vs}$ $0.8 \mu \mathrm{g} / \mathrm{g}$ at 139 days $; 0.9 \mathrm{vs} 1.3 \mu \mathrm{g} / \mathrm{g}$ at 160 days $; 1.2 \mathrm{vs} 2.0 \mu \mathrm{g} / \mathrm{g}$ at 185 days ; $\mathrm{P}<0.001$ ).

Partial correlations between fat $5 \alpha$-androstenone and age were significant at the first biopsy, whereas partial correlations with live weight were significant at all three times of measurement. In SA boars weighing $90 \mathrm{~kg}$ there was a significant correlation between fat $5 \alpha$-androstenone and all the developmental traits of the genital tract. In SW and CTRL pigs weighing $125 \mathrm{~kg}$, fat $5 \alpha$-androstenone was significantly correlated with accessory sex gland development but not with testis or epididymis weight.

From the present data it is concluded that both age and live weight had a significant effect on fat $5 \alpha$-androstenone levels in young, light boars. In older, heavier boars, age had no effect per se but live weight still had a significant influence on $5 \alpha$-androstenone concentrations. In boars weighing $90 \mathrm{~kg}$, fat $5 \alpha$-androstenone level depended on sexual maturity. When the animals were sexually mature at $125 \mathrm{~kg}$ of live weight, $5 \alpha$-androstenone level depended on the individual's potentiality for steroid production, which is probably under genetic control.
\end{abstract}

\section{Introduction.}

The testicular steroid, $5 \alpha$-androstenone ( $5 \alpha$-androst-16-ene-3-one), is one of the main compounds causing boar taint (Bonneau, 1982a). The rate of $5 \alpha$-androstenone and other steroids synthesis is regulated by pituitary LH (Carlström et al., 
1975 ; Claus and Alsing, 1976). A dramatic increase in testosterone (MeusyDessolle, 1975 ; Colenbrander et al., 1978 ; Flor Cruz and Lapwood, 1978), DHA (Tan and Raeside, 1980), estrogens (Claus and Hoffmann, 1980) and $5 \alpha$-androstenone (Claus, 1975 ; Andresen, 1976 ; Malmfors et al., 1978 ; Bonneau and Desmoulin, 1980 ; Willeke et al., 1980) production is observed around puberty. Sexual development, and therefore $5 \alpha$-androstenone production, is dependent on animal age and live weight. However, the respective influence of each factor is not known.

A first experiment was conducted (Bonneau, 1982b) to study this question by comparing boars fed two planes of nutrition in which fat $5 \alpha$-androstenone levels were determined either at similar live weights and different ages or at similar ages and different live weights. However, the results were not conclusive because growth rate differences between the groups were not sufficient to induce significant differences in fat $5 \alpha$-androstenone levels.

The present study was conducted according to a similar experimental design but wich a higher degree of restriction on a larger number of pigs exhibiting improved growth performance.

\section{Materials and methods.}

1) Animals and experimental design. - A total of 150 Large White boars from 50 litters, aged $64.7 \pm 0.3$ days (mean \pm SEM) and weighing $26.3 \pm 0.2 \mathrm{~kg}$, were given one of three treatments on a within-litter basis. The boars given treatment 1 were fed a diet containing $3090 \mathrm{kcal} \mathrm{DE} / \mathrm{kg}, 17.3 \%$ crude protein and $0.83 \%$ lysine on a liberal scale of feeding based on animal live weight (from $1.40 \mathrm{~kg}$ of feed per day at $25-30 \mathrm{~kg}$ of live weight up to $3.20 \mathrm{~kg}$ at $105 \mathrm{~kg}$ or more of live weight). Pigs given treatments 2 and 3 were offered $70 \%$ of the same diet at similar live weights.

The boars were housed in groups of 5 each and fed collectively. They could see, hear, smell and have nose-to-nose contact with females of similar age housed in adjacent pens. The boars given treatment 1 , considered as the control (CTRL), were slaughtered at about $125 \mathrm{~kg}$ of live weight. Those given treatment 2 (SW) were slaughtered at the same live weight, whereas the animals given treatment 3 (SA) were slaughtered at the same age as the controls.

The experiment was repeated four times according to the same experimental design : in autumn 1982 (experiment 1), spring and autumn 1983 (experiments 2 and 3 ) and spring 1984 (experiment 4) (30, 45, 45 and 30 boars, respectively).

2) Fat 5 5 -androstenone measurements. - The backfat of every boar was sampled at slaughter in the neck. area in all four experiments. In addition, in experiments 1 and 2, backfat biopsies were performed in the same area at around 80 and $100 \mathrm{~kg}$ of live weight in the CTRL boars, at similar live weights in SW pigs and at similar ages in SA pigs.

Fat $5 \alpha$-androstenone levels were measured by radioimmunoassay after extraction with solvents, as previously described (Claus, 1974 ; Uzu and Bonneau, 1980). The results were expressed in $\mu \mathrm{g}$ of $5 \alpha$-androstenone/g of ether extract. 
The mean ages and live weights of the boars, at the times $5 \alpha$-androstenone was measured, are shown in table 1.

\section{TABLE 1}

Age and live weight of the boars at the time of fat $5 \alpha$-androstenone measurements.

\begin{tabular}{|c|c|c|c|}
\hline \multirow{2}{*}{$\begin{array}{c}\text { Time of } 5 \alpha \text {-androstenone } \\
\text { measurement }\end{array}$} & \multicolumn{3}{|c|}{ Treatment } \\
\hline & $\begin{array}{c}1 \\
\text { CTRL }\end{array}$ & $\begin{array}{c}2 \\
\text { sw }\end{array}$ & $\begin{array}{c}3 \\
S A\end{array}$ \\
\hline \multicolumn{4}{|l|}{ First biopsy $(1-2)$} \\
\hline age (d) & $138.8 \pm 1.4$ & $168.7 \pm 2.7$ & $138.5 \pm 1.4$ \\
\hline live weight $(\mathrm{kg})$ & $80.8 \pm 0.6$ & $79.8 \pm 0.4$ & $59.5 \pm 1.4$ \\
\hline \multicolumn{4}{|l|}{ Second biopsy (1-2) } \\
\hline age (d) & $159.9 \pm 1.5$ & $202.9 \pm 3.3$ & $160.0 \pm 1.6$ \\
\hline live weight $(\mathrm{kg})$ & $101.4 \pm 0.5$ & $100.3 \pm 0.3$ & $73.2 \pm 1.9$ \\
\hline \multicolumn{4}{|l|}{ Slaughter $(1-2)$} \\
\hline age (d) & $184.8 \pm 2.1$ & $237.1 \pm 3.8$ & $184.7 \pm 2.1$ \\
\hline live weight $(\mathrm{kg})$ & $125.6 \pm 0.7$ & $125.2 \pm 0.3$ & $90.1 \pm 2.6$ \\
\hline \multicolumn{4}{|l|}{ Slaughter (1-4) } \\
\hline age (d) & $183.7 \pm 1.6$ & $241.5 \pm 2.6$ & $183.2 \pm 1.7$ \\
\hline live weight $(\mathrm{kg})$ & $126.2 \pm 0.4$ & $125.0 \pm 0.2$ & $90.7 \pm 1.6$ \\
\hline
\end{tabular}

Means \pm s.e.m.

(1-2) Experiments 1 and 2 (69 pigs).

(1-4) Experiments 1, 2, 3 and 4 (141 pigs).

3) Measurements at slaughter. - The genital tract was dissected; the testes, epididymis, seminal vesicles + prostate and bulboureihral glands were weighed and the length of the latter glands measured. The right side of each carcass was cut, and the percentages of total muscle and fat were estimated using the multiple regression equations described by Desmoulin et al. (1976). The results on genital tract development and carcass composition are presented elsewhere (Prunier et al., 1987). Only the relationships between these traits and fat $5 \alpha$-androstenone levels have been considered here.

4) Statistical analysis. - The distribution of fat $5 \alpha$-androstenone levels were skewed, so the data on these were converted to natural logarithms and almost normal distributions were obtained. Variance analysis was used to test the effects of experiments and treatments. When relevant, the effects of time of measurement and animal within treatment were also tested (fig. 1). Multiple comparison of the means was achieved using the Scheffe test.

\section{Results.}

1) Feed consumption and growth performance (table 2).

The overall levels of restriction actually achieved were 24,27 and $29 \%$ for the periods - 26-60 kg, $60-90 \mathrm{~kg}$ and $90 \mathrm{~kg}$ - slaughter respectively. Average 
daily gains were lower in restricted than in CTRL boars and did not differ significantly between SW and SA animals.

TABLE 2

Feed consumption and growth performances.

\begin{tabular}{|c|c|c|c|}
\hline \multirow[b]{2}{*}{ Live-weight period } & \multicolumn{3}{|c|}{ Treatment } \\
\hline & $\begin{array}{c}1 \\
\text { CTRL }\end{array}$ & $\stackrel{2}{\mathrm{SW}}$ & $\begin{array}{c}3 \\
\text { SA }\end{array}$ \\
\hline \multicolumn{4}{|l|}{$26-60 \mathrm{~kg}$} \\
\hline Feed consumption $(\mathrm{kg} / \mathrm{d})$ & 1.81 & 1.37 & 1.36 \\
\hline Daily gain $(\mathrm{g} / \mathrm{d})$ & $694 \pm 13^{a}$ & $476 \pm 10^{b}$ & $475 \pm 13^{b}$ \\
\hline \multicolumn{4}{|l|}{$60-90 \mathrm{~kg}$} \\
\hline Feed consumption $(\mathrm{kg} / \mathrm{d})$ & 2.69 & 2.00 & 1.95 \\
\hline Daily gain $(\mathrm{g} / \mathrm{d})$ & $941 \pm 17^{a}$ & $626 \pm 13^{b}$ & $634 \pm 15^{b}$ \\
\hline \multicolumn{4}{|l|}{$90 \mathrm{~kg}$-slaughter } \\
\hline Feed consumption $(\mathrm{kg} / \mathrm{d})$ & 3.06 & 2.16 & \\
\hline Daily gain $(\mathrm{g} / \mathrm{d})$ & $961 \pm 23^{a}$ & $616 \pm 17^{b}$ & \\
\hline
\end{tabular}

Feed consumption : boars were fed collectively. Therefore statistical analysis of individual results was not possible.

Daily gain: Means \pm s.e.m. Within rows, treatment means followed by different superscript letters were significantly different $(P<0.05)$

2) Fat $5 \alpha$-androstenone levels (fig. 1).

There was no significant effect of season (experiments $1+2$ vs $2+4$ ) on fat $5 \alpha$-androstenone level. At the time of first biopsy laround $80 \mathrm{~kg}$ of live

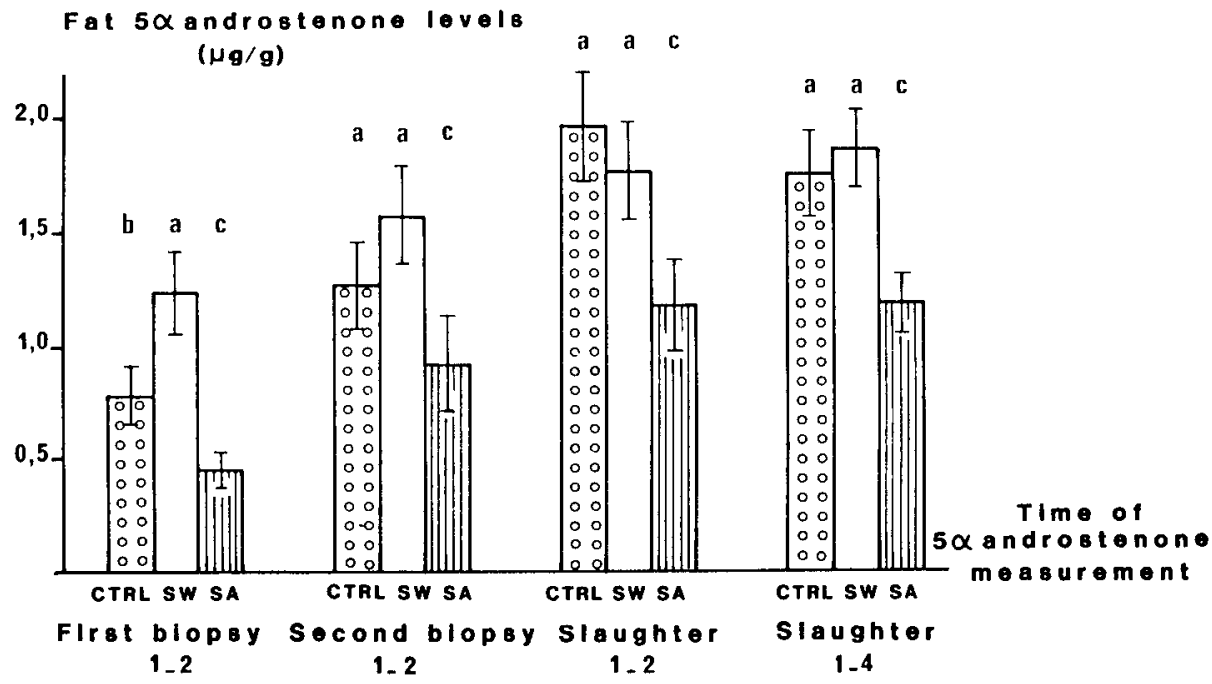

FIG. 1. - Fat $5 \alpha$-androstenone levels (means + s.e.m.).

(1-2) Experiments 1 and 2 (69 pigs).

(1-4) Experiments 1, 2, 3 and 4 (141 pigs).

Significance of differences : $a-b: P<0.05 ; a-c: P<0.001 ; b-c: P<0.001$. 
weight), fat $5 \alpha$-androstenone was significantly higher in SW boars, aged 169 days, than in CTRL boars which were 30 days younger. At higher live weights there was no significant difference between SW and CTRL boars, although SW animals were 43 and 52-55 days older than CTRL ones at 100 and $125 \mathrm{~kg}$, respectively.

At all three times of measurement, fat $5 \alpha$-androstenone levels were significantly lower in SA than in CTRL boars.

\section{3) Correlations between fat $5 \alpha$-androstenone levels and other traits.}

Age and live weight (table 3). - Fat $5 \alpha$-androstenone level was significantly correlated with animal live weight. The correlation of fat $5 \alpha$-androstenone with age was higher at the first biopsy than at subsequent measurements. At all the three times studied, fat $5 \alpha$-androstenone was more closely related with live weight than with age.

TABLE 3

Coefficients of correlation between fat $5 \alpha$-androstenone level and age or live-weight.

\begin{tabular}{|c|c|c|c|c|}
\hline \multirow{2}{*}{$\begin{array}{c}\text { Time of } 5 \alpha \text {-androstenone } \\
\text { measurement }\end{array}$} & \multicolumn{2}{|c|}{$\begin{array}{l}\text { Total correlation } \\
\text { with }\end{array}$} & \multicolumn{2}{|c|}{$\begin{array}{l}\text { Partial correlation(S) } \\
\text { with }\end{array}$} \\
\hline & Age & Live-weight & Age. LW & LW. age \\
\hline First biopsy (1-2) & $0.32^{* *}$ & $0.38^{* *}$ & $0.28^{*}$ & $0.28^{*}$ \\
\hline Second biopsy (1-2) & $0.11 \mathrm{NS}$ & $0.32^{* *}$ & $0.05 \mathrm{NS}$ & $0.29^{*}$ \\
\hline Slaughter $(1-2)$ & $0.22^{+}$ & $0.44^{* * *}$ & $0.05 \mathrm{NS}$ & $0.43^{* * *}$ \\
\hline Slaughter (1-4) & $0.26^{* *}$ & $0.32^{* * *}$ & $0.14 \mathrm{NS}$ & $0.24^{*}$ \\
\hline
\end{tabular}

(S) Partial correlation of fat $5 \alpha$-androstenone with :

- age, common effect of live weight being eliminated (age. LW),

- live-weight, common effect of age being eliminated (LW.age).

(1-2) Experiments 1 and 2 (69 pigs).

(1-4) Experiments 1, 2, 3 and 4 (141 pigs).

Significance of the coefficients of correlation: NS - Non significant ; $P<0.10 ;{ }^{*} P<0.05$; ** $P<0.01 ; * * * P<0.001$.

\section{TABLE 4}

Coefficients of correlation between fat $5 \alpha$-androstenone levels and genital tract development traits.

\begin{tabular}{|c|c|c|c|}
\hline \multirow{2}{*}{$\begin{array}{c}\text { Genital tract } \\
\text { development traits }\end{array}$} & \multicolumn{3}{|c|}{ Treatment } \\
\hline & CTRL & SW & SA \\
\hline \multicolumn{4}{|l|}{ Weight of : } \\
\hline - testes & $0.19 \mathrm{NS}$ & -0.04 NS & $0.50^{* * *}$ \\
\hline - epididymis & $0.13 \mathrm{NS}$ & $0.06 \mathrm{NS}$ & $0.50^{* * *}$ \\
\hline - seminal vesicles & $0.44^{* *}$ & $0.31^{*}$ & $0.53^{* * *}$ \\
\hline - bulbourethral glands & $0.71^{* * *}$ & $0.56^{* * *}$ & $0.72^{* * *}$ \\
\hline $\begin{array}{l}\text { Length of bulbourethral } \\
\text { glands }\end{array}$ & $0.63^{* * *}$ & $0.61^{* * *}$ & $0.66^{* * *}$ \\
\hline
\end{tabular}

Significance of the coefficients of correlation: NS Non significant ; ${ }^{*} P<0.05 ;{ }^{*} P<0.01$; *** $\mathrm{P}<0.001$. 
After the common effect of age was eliminated, partial correlations between fat $5 \alpha$-androstenone and live weight were slightly lower than the total correlations, but still significant. Partial correlations with age (the common effect of live weight eliminated) was only significant at the first biopsy.

Growth rate and carcass composition. - The coefficients of correlation between fat $5 \alpha$-androstenone levels and average daily gain, percentage of muscle or of fat in the carcass were very low $(-0.21<r<+0.18)$.

Genital tract development (table 4). - In CTRL and SW boars slaughtered at $125 \mathrm{~kg}$ of live weight, fat $5 \alpha$-androstenone levels were correlated with the development of the seminal vesicles and bulbourethral glands but not with the weight of the testes or epididymis. In SA boars slaughtered at $70 \mathrm{~kg}$, there was a significant relationship between $5 \alpha$-androstenone and all the developmental traits of the genital tract. The relationships between $5 \alpha$-androstenone level and the weight of the testes in SA boars or of the bulbourethral glands in all boars are shown in figures 2 and 3.

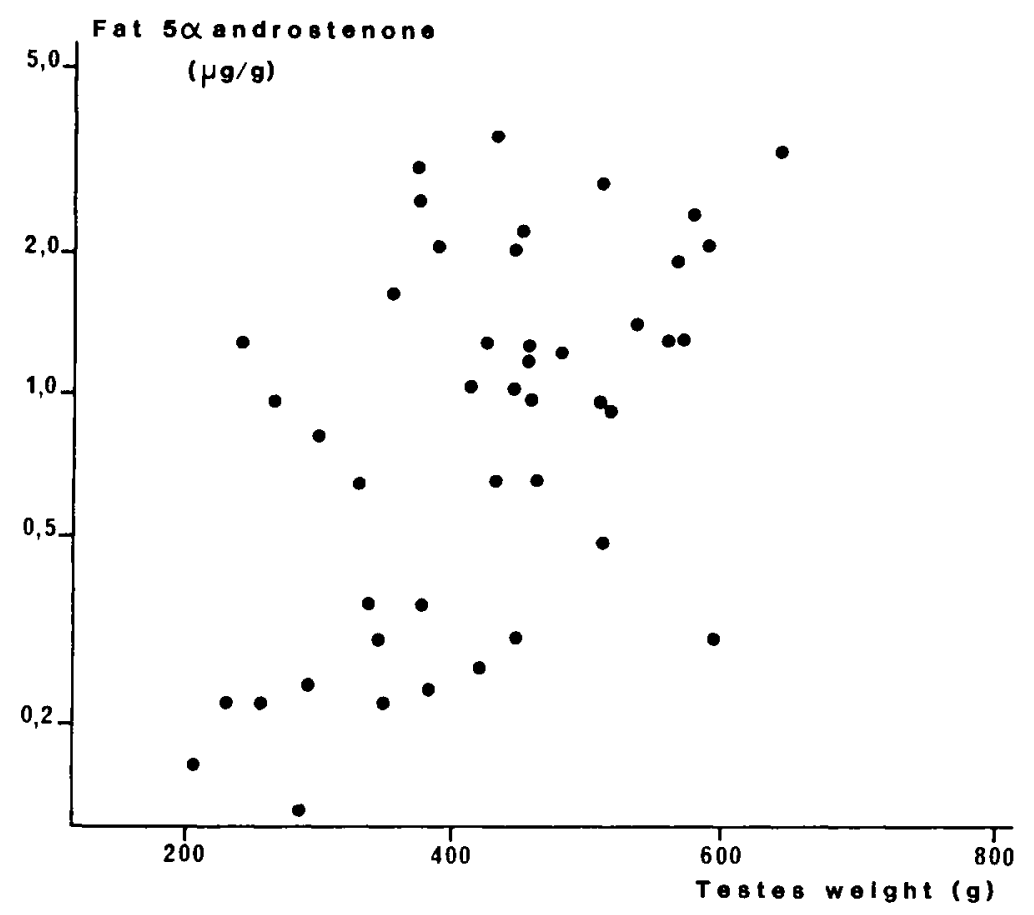

FIG. 2. - Distribution of fat $5 \alpha$-androstenone level against testes weight in SA boars.

\section{Discussion.}

1) The effect of age and live weight on $5 \alpha$-androstenone leve/s. - At $80 \mathrm{~kg}$ of live weight, SW boars exhibited higher $5 \alpha$-androstenone levels than CTRL 


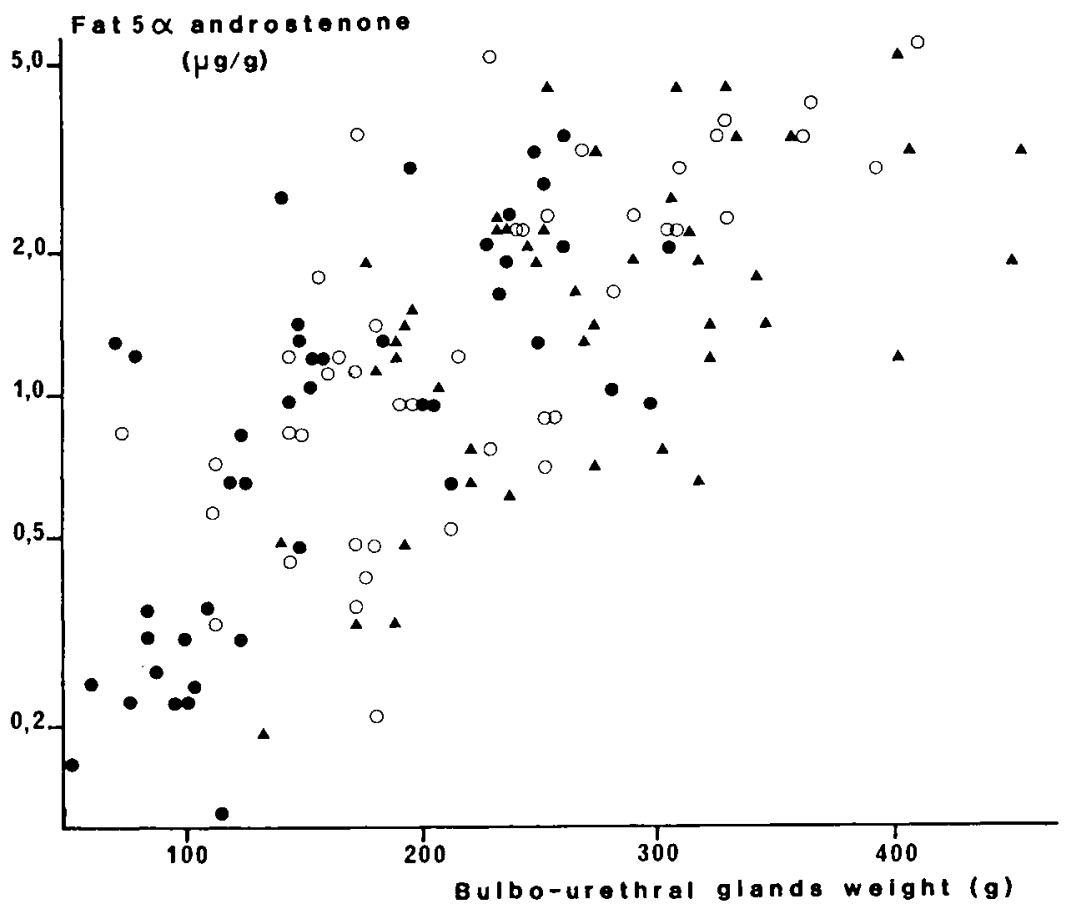

FIG. 3. - Distribution of fat $5 \alpha$-androstenone level against bulbourethral glands weight in overall population.

(1)) CTRL boars ; (A) SW boars ; ( $\bullet$ ) SA boars.

boars which were 30 days younger. The influence of age in young, light animals (139-169 days and $60-80 \mathrm{~kg}$ at first biopsy) was also demonstrated by the significant relationship between fat $5 \alpha$-androstenone and age. That influence is an actual effect of age since partial correlation between $5 \alpha$-androstenone levels and age, after elimination of live weight effect, was significant.

This effect of age was no longer observed in older, heavier boars 1160 239 days and $73-126 \mathrm{~kg}$ at second biopsy and at slaughter). Indeed, there was no significant difference between SW and CTRL boars, although the former were 43 to 55 days older than the latter. Moreover, partial correlations of fat $5 \alpha$-androstenone with age, after elimination of the live weight effect, were not significant. These findings are consistent with the results of Mosenthin et al. (1984) who found no difference in $5 \alpha$-androstenone levels at $100 \mathrm{~kg}$ between groups of 12 and 6 boars aged 171 and 205 days, respectively.

For boars of similar ages, fat $5 \alpha$-androstenone levels were higher in CTRL than in SA boars which where 21, 28 and $36 \mathrm{~kg}$ lighter at 139, 160 and 185 days of age, respectively. Such a difference is an actual effect of live weight since partial correlations of fat $5 \alpha$-androstenone levels with live weight, after elimination of age effect, were significant at all three times of measurement.

Thus, the present data demonstrate that both age and live weight have an effect on fat $5 \alpha$-androstenone levels in young, light boars aged about 140- 
170 days and weighing $60-80 \mathrm{~kg}$. Later on, age has no significant influence, whereas live weight still has an effect on $5 \alpha$-androstenone levels. Such findings have practical implications. If boars are killed at light commercial weight, a reduced growth performance induced by excessive feed restriction will increase fat $5 \alpha$-androstenone levels at slaughter. On the other hand, if they are slaughtered at heavier commercial weights of $100 \mathrm{~kg}$ or more, there is no adverse influence of feed restriction on fat androstenone levels at slaughter.

2) Relationship between fat $5 \alpha$-androstenone levels and genital tract development. - The existence of close relationships between fat $5 \alpha$-androstenone levels and seminal vesicle or bulbourethral gland development has been previously reported (Forland et al., 1980 ; Uzu and Bonneau, 1980 ; Bonneau and Russeil, 1985).

The SA boars weighing $90 \mathrm{~kg}$ were not sexually mature at slaughter, as demonstrated by their lower genital tract development compared to SW or CTRL boars (Prunier et al., 1987). In such pigs, the positive relationship between $5 \alpha$-androstenone level and testis or epididymis weight is thus the result of between-animal variability in sexual maturity.

SW and CTRL boars weighing $126 \mathrm{~kg}$ were sexually mature at slaughter. In such boars, $5 \alpha$-androstenone level was not related to sexual maturity since there was no significant correlation with testis or epididymis weight, and fat $5 \alpha$-androstenone level depended on between-animal variability in the potentiality for steroid production, as shown by the significant correlations with seminal vesicle or bulbourethral gland development. Indeed, both glands are well-known target organs for androgens and estrogens in male pigs (Joshi and Raeside, 1973; Morat et al., 1980 ; Booth, 1980, 1983 ; Lauwers et al., 1981).

\section{Conclusion.}

The results of the present experiment demonstrate that both age and body weight influence fat $5 \alpha$-androstenone levels in young, light boars. In older, heavier boars, the influence of body weight is greater than the effect of age. However, most fat $5 \alpha$-androstenone variability is not dependent on developmental traits. Further studies are needed to investigate the genetic factors controlling both sexual development and the potentiality for steroid production.

Recu en septembre 1986. Accepté en décembre 1986.

Acknowledgements. - The author wishes to thank A. Prunier, M. Etienne and J. Noblet for their help in preparing the manuscript. He is also indebted to Dr Claus (Universität Hohenheim, FRG), Dr Hafferl (Institute of Organic Chemistry Synthex, Palo Alto, U.S.A.) and $\mathrm{Dr}$ Hewitt (Organon Laboratories, Newhouse, U.K.) who generously provided the antiserum and the tritiated and unlabelled $5 \alpha$-androstenone, respectively. 
Résumé. Influences respectives de l'âge et du poids sur la teneur en $5 \alpha$-androsténone du tissu adipeux de jeunes verrats nourris selon deux plans d'alimentation.

Le but de cette expérience est de déterminer lequel des deux critères âge ou poids des animaux est le facteur déterminant de la teneur en $5 \alpha$-androsténone du tissu adipeux des porcs mâles entiers. Trois groupes de 50 verrats sont nourris selon un plan d'alimentation libéral (CTRL) ou restreint de $30 \%$ (SW et SA). La teneur en $5 \alpha$-androsténone du tissu adipeux est mesurée à trois reprises pour chaque animal, 2 fois sur une biopsie puis à l'abattage, soit au même poids (SW) soit au même âge (SA) que les porcs témoins (CTRL).

Les verrats SW (âgés de 169 jours) présentent des teneurs en $5 \alpha$-androsténone plus élevées que celles des CTRL (âgés de 139 jours) au moment de la première biopsie, à $80 \mathrm{~kg}$ de poids vif $(1,2$ contre $0,8 \mu \mathrm{g} / \mathrm{g} ; \mathrm{P}<0,05)$. Au moment de la deuxième biopsie (100 $\mathrm{kg}$ de poids vif) ou à l'abattage (125 kg), il n'y a aucune différence significative entre les groupes $S W$ et $C T R L$, bien que les porcs $S W$ soit plus âgés que les CTRL de 43 à 55 jours. Au trois moments de mesure, la teneur en $5 \alpha$-androsténone est plus faible dans le groupe SA que dans le groupe CTRL où les verrats sont plus lourds de 21 à $36 \mathrm{~kg}(0,5$ contre $0,8 \mu \mathrm{g} / \mathrm{g}$ à 139 jours ; 0,9 contre $1,3 \mu \mathrm{g} / \mathrm{g}$ à 160 jours ; 1,2 contre $2,0 \mu \mathrm{g} / \mathrm{g}$ à 185 jours ; $\mathrm{P}<0,001)$.

Les coefficients de corrélation partielle entre la teneur en $5 \alpha$-androsténone et l'âge sont significatifs au moment de la première biopsie alors que les corrélations partielles avec le poids vif sont significatives aux trois temps de mesure. Chez les verrats SA (pesant $90 \mathrm{~kg}$ ) il existe une corrélation significative entre la teneur en $5 \alpha$-androsténone et l'ensemble des critères de développement de l'appareil génital. Chez les verrats SW et CTRL (pesant $125 \mathrm{~kg}$ ) la teneur en $5 \alpha$-androsténone est significativement corrélée avec le développement des glandes annexes mais pas avec le poids des testicules ou des épididymes.

En conclusion, chez les verrats jeunes et légers, les deux critères âge et poids ont une influence significative sur la teneur en $5 \alpha$-androsténone. Dans le cas des porcs plus lourds et plus âgés l'âge n'a plus aucun effet propre alors que le poids vif conserve une influence significative sur les concentrations en $5 \alpha$-androsténone. Chez des verrats aux alentours de $90 \mathrm{~kg}$ de poids vif, la teneur en $5 \alpha$-androsténone du tissu adipeux dépend du degré de maturité sexuelle des animaux. Par contre, lorsque les animaux ont atteint leur pleine maturité sexuelle, vers $125 \mathrm{~kg}$ de poids vif, les concentrations en $5 \alpha$-androsténone dépendent des potentialités individuelles de production de stéroïdes, qui sont probablement sous contrôle génétique.

\section{References}

ANDRESEN O., 1976. Concentration of fat and plasma $5 x$-androstenone and plasma testosterone in boars selected for rate of body weight gain and thickness of backfat during growth, sexual maturation and after mating. J. Reprod. Fert., 48, 51-59.

BONNEAU M., 1982a. Compounds responsible for boar taint with special emphasis on androstenone a review. Livest. Prod. Sci, 9, 687-705.

BONNEAU M., 1982b. Influence de l'âge, du poids et de la vitesse de croissance sur la teneur en androsténone des graisses de jeunes porcs mâles entiers. Ann. Zootech., 31, 27-36.

BONNEAU M., DESMOULIN B., 1980. Evolution de la teneur en androsténone du tissu adipeux dorsal chez le porc mâle entier de type Large-White: variations selon les conditions d'élevage. Reprod. Nutr. Dévelop., 20, 1429-1437.

BONNEAU M., RUSSEIL P., 1985. The size of Cowper's (bulbourethral) glands as an estimate of boar taint on the slaughter line. Livest. Prod. Sci., 13, 169-178.

BOOTH W. D., 1980. A study of some major testicular steroids in the pig in relation to their effect on the development of male characteristics in the prepubertally castrated boar. J. Reprod. Fert., 59, 155-162.

BOOTH W. D., 1983. Development of some male characteristics supported by oestrone but not dehydroepiandrosterone in the boar. J. Reprod. Fertil., 68, 9-16.

CARLSTRÖM K., MALMFORS B., LUNDSTRÖM K., EDOVIST L. E., 1975. The effect of H.C.G. on blood plasma levels of $5 x_{x}$-androstenone and testosterone in the boar. Swed. J. agric. Res., 5, 15-21. 
CLAUS R., 1974. Dosage radioimmunologique de $5 \alpha$-androst-16-ene-3-one, stéroïde responsable de l'odeur de verrat, dans le tissu adipeux des porcs. C. R. Acad. Sci. Paris, Sér. D, 278. 299-302.

CLAUS R., 1975. Messung des Ebergeruchsstoffes im Fett von Schweinen Mittels eines Radioimmunotests. 1-Mitteilung: Geruchsdepotbildung in Abhängigkeit von Alter. Z. Tierz. Zuchtungsbiol., 92, 118-126.

CLAUS R., ALSING W., 1976. Einfluss von Choriongonadotropin, Haltungsänderung und sexueller Stimulierung auf die Konzentrationen von Testosteron im Plasma sowie des Ebergeruchsstoffes im Plasma und Fett eines Ebers. Berliner Müenchener Tierärzt/. Wochenschr., 89, 354-358.

CLAUS R., HOFFMANN B., 1980. Oestrogens compared to other steroids of testicular origin, in blood plasma of boars. Acta endocrinol., 94, 404-411.

COLENBRANDER B., DE JONG F. H., WENSING C. J. G., 1978. Changes in serum testosterone concentrations in the male pig during development. J. Reprod. Fert., 53, 377-380.

DESMOULIN B., GRANDSARD P., TASSENCOURT L., 1976. Les critères d'appréciation de la composition anatomique de la carcasse de porc et des pièces de découpe. Principes généraux et difficultés de classification. Journées Rech. Porcine en France, 8, 89-98.

FLOR CRUZ S. V., LAPWOD K. R., 1978. A longitudinal study of pubertal development in boars. Int. J. Androl., 1, 317-380.

FORLAND D. M., LUNDSTRÖM K., ANDRESEN O., 1980. Relationship between androstenone in fat, intensity of boar taint and size of accessory se glands in boars. Nord. Veterinaermed, 32, 201-206.

JOSHI H. S., RAESIDE J. I., 1973. Synergistic effects of testosterone and oestrogens on accessory sex glands and sexual behaviour of the boar. J. Reprod. Fert., 33, 411-423.

LAUWERS H., GYSELBRECHT C., SIMOENS L., NICAISE M., DE VOS N. R., 1981. Morphological detection of hormone treatment in barrows. Archiv. Lebensmitte/hyg., 32, 77-82.

MALMFORS B., LUNDSTRÖM K., HANSSON H., 1978. Interrelations between boar taint, $5 \alpha$-androstenone and fatty acid composition in pigs. Swed. J. agric. Res., 8, 161-169.

MEUSY-DESSOLLE N., 1975. Variations quantitatives de la testostérone plasmatique chez le porc mâle, de la naissance à l'âge adulte. C. R. Acad. Sci. Paris, Sér. D, 281, 1875-1878.

MORAT M., LOCATELLI A., TERQUI M., CHEVALIER M., CHAMBON M., DUFAURE J. P., 1980. Effets de l'hypophysectomie puis de l'administration de la gonadotropine HCG sur le taux de testostérone plasmatique et sur la structure de l'épididyme et des glandes accessoires chez le verrat (Sus scrofa L.). Reprod. Nutr. Dévelop., 20, 61-76.

MOSENTHIN R., HENKEL H., WISSENBACH W., 1984. Vergleich von Methoden zur Bestimmung des Ebergeruchs bei männlichen Mastschweinen unter Berücksichtigung einer unterschiedlichen Fütterungsintensität. 35th annu. Meet. of the E.A.A.P., 6-9 august, The Hague.

PRUNIER A., BONNEAU M., ETIENNE M., 1987. Effects of age and live weight on the sexual development of gilts and boars fed two planes of nutrition. Reprod. Nutr. Dévelop., 27 (3) (sous presse).

TAN H. S., RAESIDE J. I., 1980. Developmental patterns of plasma dehydroepiandrosterone sulphate and testosterone in male pigs. Anim. Reprod. Sci., 3, 73-81.

UZU G., BONNEAU M., 1980. Relations entre la production spermatique et la teneur en androsténone dans les graisses du jeune verrat. Ann. Zootech., 29, 23-30.

WILLEKE H., CLAUS R., PIRCHIJER F., ALSING W., 1980. A selection experiment against $5 \alpha$-androst-16-ene-3-one, the boar taint steroid, in adipose tissue of boars. $Z$. Tierz. Zuchtungsbiol., 97, 86-94. 